\author{
Antonii Palamar ${ }^{1}$
}

\title{
THE INFLUENCE OF THE SALAFI MOVEMENT ON THE POLITICAL TRANSFORMATION OF EGYPT IN 2011-2013
}

Keywords: Middle East, Muslim Brotherhood, Saudi Arabia, Qatar, political Islam, Islamism, Wahhabism.

\begin{abstract}
Until 2011, Salafi movement held itself aloof from politics. However, Arab Spring resulted in an opportunity to create their own political parties. Egyptian Salafists were the first to follow this path after the fall of the Hosni Mubarak regime. The emergence of these parties proved to be beneficial for the development of Arab democracy. By their convictions, the Salafists are extremely conservative and more radical than the Muslim Brotherhood. Despite its conservatism, the political force used peaceful means to fight for change, attracted a significant part of Arab society to participate in legal politics, and also added diversity to the spectrum of Islamist parties, preventing any one force from claiming that it represented the entire Muslim community. But soon the rise in popularity of jihadist organizations, which call to fight for the implementation of Islamist ideas not by legal political, but by violent methods, undermined the influence of Salafi parties. In addition, discrediting of the Salafi movement was largely influenced by Saudi policy, the main purpose of which was to counter the Muslim Brotherhood inside Egypt. As a result, most of the ultra-conservative forces became Wahhabi, which led to discord within the Egyptian Salafists. The one part of the movement, which continued to support the Brothers, suffered a political defeat with them after the 2013 military coup. The other part, which sided with the military elite, as a result of these actions completely lost support among the population. This article analyzes the process of the Salafi movement entering the political arena in Egypt, the dynamics of its relations with the Muslim Brotherhood and the ideological differences between them. The article also examines the influence of Saudi Arabia on Egyptian Salafism and explains the main differences between Salafism and Wahhabism in the context of this influence.
\end{abstract}

1 Postgraduate Student at the Department of Political Science, National University of “Kyiv-Mohyla Academy”, Tarlandash@gmail.com. ORCID: 0000-0003-4927-8241. 


\section{INTRODUCTION}

The unprecedented mass riots during the Arab Spring of 2011 drew researchers' and analysts' attention to Islamist organizations that sought to establish Islamic rule in the countries once ruled by secular dictators. That brought to the fore Egyptian "Muslim Brotherhood." This organization caught the eye of the West, when its Freedom and Justice Party (FJP) took control over Egyptian parliament and president's office, eliminated the military elite, and gained absolute state power.

Lower priority was given to the main Islamist opponents of the Muslim Brotherhood, members of the hard line fundamentalist, extremist Salafi movement, although the latter ranked second in the 2012 parliamentary elections in Egypt. The situation changed rapidly as this movement transformed from a rather insignificant and apolitical organization into an influential Islamist force. Already after 2012 experts became more interested in radical Islamists than in Brothers primarily due to a change in the course of "An-Nur," the main Salafist party, which stopped cooperation with Brothers and later sided with the opposition.

Relevance of this topic for the United States and all European nations is driven by the need to develop and modify their own principles for countering Islamic extremism and international terrorism and also due to the reformation of its domestic policy toward Arab minorities, caused by the crisis of multiculturalism. Bernard Lewis (Lewis, 1988), John Esposito (Esposito, 1992), and Edward Said (Said, 1997) are among the researchers, who addressed the issue of political Islam. They have focused on the critique of the Western research method of modern Islamic political reality through the use of a civilizational approach and the principles of Eurocentrism. American researcher Quintan Wiktorowicz (Wiktorowicz, 2006) was among those first who drew attention to political Salafists and thoroughly analyzed their basic ideological principles.

For Russia, the Middle East issues, especially the current foreign policy trends of Saudi Arabia and Qatar, are of extreme significance, as the state faces the problem of Islamic extremism (similar to the West's), spread in Chechnya and Dagestan in the form of Wahhabism. The works of Marat 
Rajbadinov (Razhbadinov, 2013) and Irina Tsaregorodtseva (Tsaregorodtseva and Ibragimov, 2018) are among the leading studies of the modern Salafi movements.

\section{IDEOLOGICAL CORE OF WAHHABISM AND SALAFISM}

Salafism is one of the most uncompromising movements in Islam; it does not recognize the possibility of an agreement with the forces that allegedly pose a direct threat to Islam and the Islamic order. The fact that the main political party of the Egyptian Salafists is called al-Nour most likely has its source in the twenty-fourth surah of the Qur'an "Surah AlNour" ("Surah of the World"), in which Allah represents the need to cleanse society from adultery and obscenity in words and deeds and also speaks of the cruel punishment to those who refuse to worship Allah and follow his teachings. "Surah Al-Nur" is a concentration of the postulates of the Islamic social order, which excludes any non-Islamic freedom in society, secularism and, although it is not directly indicated, multi-religious. The latter postulate was voiced by Hassan Abu al-Ashbaou, one of the leaders of Salafism in Egypt, on March 19,2009, on the air of Egyptian TV channel "Al-Nas" he stated that Shiites were a greater enemy of Islam than Jews (Dagher, 2012). Other Salafist leaders, who gained free access to Arab television thanks to the overthrow of secular regimes after "Arab Spring" and the support provided by Saudi Arabia, express almost the same ideas.

The history of the first Salafists in its present day meaning (then called "Kharijites" - "those who left," "separated") dates back to the life of Muhammad, when some of the first Muslim communities doubted the special role of the Prophet and did not believe that they had to obey. Sunnah (second most important source of Islamic doctrine after the Qur'an) describes that Prophet Muhammad, who did not consider Kharijites as Muslims, said that everything they had in common was only reading the Qur'an, but "they will fly through the religion's dogma like an arrow flies through the target" (Mukhtasar Sahih Muslim. Hadit, No. 1066). 
Over time, based on the teachings of the Kharijites, two religious and political groups were formed whose active work on the spread of Islam with widespread use of violence brought them worldwide fame - Wahhabists and Salafists.

A key problem with much of the literature is that these two concepts are often used as synonyms, however, such an approach is flawed. Although these currents refer (as a result of interaction) to almost identical principles of faith, they adhere to different methods of achieving their goals.

Equation of the concepts of "Wahhabism" and "Salafism" is not entirely fair: Wahhabism is only one of the directions of movement in Sunni Islam, generally called "Salafism." Professor of the University of California Khaled Abu al-Fadel claimed that in the XX century Wahhabism was forced to take the name "Salafism" because under its authentic name it had no chance to spread beyond the Arabian Peninsula. The inclusion of Wahhabism in Salafism was necessary because Salafism was a much more reliable Islamic paradigm. This inclusion was possible because Salafism and Wahhabism share a common methodology and essence, except that Salafism is more open to different opinions and interpretations. Therefore, Wahhabism had to renounce its extreme intolerance and accept the symbolism and terminology of Salafism (Mohamed, 2015, p. 49).

Contrary to popular stereotypes, the Salafists were initially more tolerant than the Wahhabis. For example, they were tolerant to the cults of worship of saints and graves that where widespread in many Muslim countries. During the European colonization of the Middle East, the Salafists tried to attract as many supporters as possible, and therefore did not run counter to the masses. They believed that the solution to political and social problems was a return to their idealized Islamic origins. In the second half of the twentieth century, when more and more Salafists began to be repressed by secular authorities, many fled to Saudi Arabia, where Wahhabism is the state religion. There they were included in the system of state religious authorities, which later led to the mutual influence of these two Islamic movements.

In order to understand the difference between modern Salafism and Wahhabism, one should borne in mind that there are different currents among the Salafists themselves. Islamic studies identify three common 
groups - purists ("scientific Salafists"), who preach true, in their view, Islam, without setting any political goals, and reject violence; political Salafists, who advocate the creation of a God-pleasing society within the Islamic state, and finally, the "jihadist Salafists," ready for violence in the name of establishing Islamic caliphate (Wiktorowicz, 2006). The latter are outnumbered though.

Other, similar categorizations of Salafism types could be found in M. Rajbadinov's research. Referring to Egyptian analysts, he mentions six currents within Egyptian Salafism: 1) traditional Salafi school, 2) Salafi pragmatists, 3) Madhalit, 4) Sururites, 5) Salafi Orthodox current, 6) Salafi jihadist. (Razhbadinov, 2013, p. 280). This typology does indeed cover a wide range of different currents within Salafism, however, the difference between some of them is insignificant and therefore they might often belong to one group.

In addition to scientific, political, and jihadist Salafism, the Russian arabist I. Tsaregorodtseva also singles out the ultraconservative, to which the "Islamic Association" (al-jamaa al-islamiya) belongs. Its goals are not fully implicit, nonetheless, their position on a number of issues has become public. Egyptian ultraconservatives often comment on the problems of interfaith relations in the country, in particular, they criticize the Copts, considering them collaborators (Tsaregorodtseva and Ibragimov, 2018, p. 13). These Salafi groups are vehemently against music and persist in female circumcision. The destruction of the pyramids and the closure of the Ministry of Tourism were the most resonant initiative of the Egyptian ultraconservatives (Egerton, 2011).

Consequently, Wahhabis could be classified only as scientific or political Salafists. The obvious difference is that Wahhabis remain loyal to the royal al-Saud dynasty, and Wahhabism is the state religion in Saudi Arabia. That is why they were often credited with protecting Saudi interests in other predominantly Arab countries. On the other hand, the Salafists seek to create a purely Islamic state without any secular power inherent to kingdom.

Since no other key differences have been found between these movements, and modern Salafism is now almost entirely indirectly supported by the Saudi royal dynasty, most observers miss the Saudi specificity of 
Wahhabism by equating it with Salafism. Moreover, even Wahhabis call themselves Salafists, which speaks of the universality of this concept. The followers of orthodox Salafism perceive the name "Wahhabis" given to them in the Ottoman Empire as contemptuous and offensive, as it implies devotion to al-Wahhab (one of the theorists of Salafism) and not to God.

For all intents and purposes, both of these groups share basic ideological principles, including: 1 . Strict monotheism; 2 . Refusal to submit to any generally accepted authority including Muhammad himself; 3 . Widespread application of the "takfir" principle, when all Muslims who disagree with the Salafists, especially those who have committed grave sins, are declared "infidels," which allows them to be deprived of property and life itself; 4. Strict rationalism and literalism in understanding and applying the provisions of the Qur'an; 5. A ban on wearing expensive clothes and jewelry; 6. Struggle against "innovations," which meant abolishing everything that the Salafists did not agree with; 7. General equality in the ummah (Muslim community - worldwide - the Islamic nation).

A specific attitude to power lies at the core of the ideology of Salafism: the legitimacy of God, whom the followers of Salafism must defend against any internal and external threat, the only legitimacy that exists on earth (Wight, 2009, p. 104).

Modern Salafism is based on a strict interpretation of Islam and urges Muslims to return to the original teachings of Qur'an, as well as to perceive religion as the earliest generations of Muslims - the companions of the Prophet - used to do it. From the point of view of the Salafists, non-Islamic teachings have poisoned the essence of "true" Islam for centuries and these impurities must be thrown out of the Islamic way of life.

\section{RELATIONSHIP BETWEEN THE MUSLIM BROTHERHOOD AND THE SALAFISTS IN EGYPT}

Salafism did not only take its ideological roots in Egypt. In 1912, the oldest Egyptian Salafist organization, the "Legal League," was founded, and since 1926 there has been another influential Salafist group called the Association of Sunni Muhammad (Jamiat Ansar al-Sunni al Muhammad). 
The activities of these organizations were purely propagandistic and educational, and their leaders emphasized their apolitical nature, thus contrasting themselves with the ideologues of "traditional" Islamism (Tsaregorodtseva and Ibragimov, 2018, p. 12).

Salafists appear to be a minority both among Muslims and Islamists around the world. Unlike the Muslim Brotherhood, the Salafists are not part of the same organization. This movement consists of a mass of local preachers, public organizations, and recent political parties, which are not always united by a common ideology, as indicated by the Egyptian events after the "Arab Spring."

The first modern Salafi movements that emerged in Egypt in the early twentieth century had a lot of common with the Muslim Brotherhood. A study of the activities of ultraconservative Islamism in the twentieth century provides an opportunity to check that their efforts, like those of the "Brothers," were aimed at social and educational work and exclusion from politics. Both sought the potential for future reforms and the prosperity of the Muslim community in the life of the first generations of Muslims. Both adopted an anti-colonial rhetoric. Hassan al-Banna, the founder of the Muslim Brotherhood, even called his Association an organization that produces "Salafi message" (Mitchell, 1993, p. 14).

However, initially insignificant differences between the Salafists and the Muslim Brotherhood over time became fundamental. Salafist movements emerged as a force that used both radical and peaceful methods of struggle and propaganda. These include the Egyptian organization "Salafi Call" (ad-Daawa al-Salafiyya), formed in the 1970s on the basis of youth Islamic associations. In contrast to the paramilitary movements that declared the official institutions of power as their enemies, the "Salafi Call" considered the Muslim Brotherhood to be its chief rival. According to the ideologues of this movement, the Muslim Brotherhood distorted the true doctrine of Islam and became a part of political struggle instead of being engaged in science and education (Tsaregorodtseva and Ibragimov, 2018, p. 10).

Certainly, a few years after its emergence, the Muslim Brotherhood embarked on the path of political activism, intending to pursue its goals using affordable political methods - participation in elections of all levels 
and cooperation with the secular parties. The Salafists, on the other hand, fundamentally avoided participating in politics and believed that politics should be used only by state power. Instead, they focused their main efforts on social work and propaganda.

By the end of the first decade of the $21^{\text {st }}$ century, Salafism had spread throughout the Arab world, primarily in Egypt and Tunisia. Both the number of its supporters and the institutional scope have increased. Public organizations engaged in charity also joined this movement. They were not yet official political parties, mainly because they lived under autocratic regimes, but were slowly creating the infrastructure for such organizations. It such a circumstances, the Salafists met the Arab Spring.

The case of the Egyptian Salafists could be called the most vivid. As well as the Muslim Brotherhood, they appeared to be unprepared for popular outrage, led mainly by youth groups, and for the waves, aimed at destroying the decades-old secular autocratic regimes. Over time, the Salafists managed to throw the non-Islamic forces that played a crucial role in the overthrow of President Hosni Mubarak, into the shade. But they did not have the political mechanisms that the Muslim Brotherhood managed to create in 80 years. As a result, various Salafist forces, that were trying to assert themselves in Egypt after the overthrow of the authoritarian regime, emerged.

Some Egyptian Salafist organizations have applied to register as political parties. Two of them have emerged among the Salafists, "al-Nour" and "al-Asala". These parties have formed an Islamist coalition with the political wing of the former jihadist group "Al-Gamaa al-Islamiya" (Creation and Development Party) (Bokhari, 2012). This alliance managed to get more than a quarter of all votes in the 2012 parliamentary elections and ranked second after the Muslim Brotherhood. Al-Nour was able to attract to its ranks numerous authoritative Islamists, who for some reasons failed to join Muslim Brotherhood. Despite the fact that the leaders of Salafi groups have different attitudes to the institution of democratic elections, al-Nour has managed to reach a compromise. A distinction was made between the "procedures of democracy" that the Salafists welcome and the "philosophy of democracy" that they reject because sovereignty cannot belong to the people, it belongs only to God (Lacroix, 2012). 
The most important aspect of Salafist participation in mass politics is that they joined the electoral process after decades of condemning democracy, which they called a non-Islamic phenomenon. In other words, the Salafists eventually adopted the Muslim Brotherhood tactics, although by this time, they had fiercely rejected it. Such a transformation was more a hasty decision than a result of natural ideological evolution.

The Salafists have not simply become the victim of weak political development. They faced intellectual contradictions and inconsistencies. On the one hand, they wanted to be part of the new democratic order and a major political player. On the other hand, they took a radical position, which required them to impose on the entire Arab and Muslim world a harsh Salafist interpretation of the Islamic law. They wanted to establish an order that created problems not only for secular forces, Christians, Jews, and other minorities, but also for moderate Islamists, such as the Muslim Brotherhood.

During the revolution of 2011, differences between the "Brothers" and the Salafists become fundamental and extended to the foundations of the Egyptian legal system. The Salafists wanted to particularize and uncompromisingly enshrine the foundations of Sharia law in the Egyptian constitution. According to them, Sharia should be the only source of law in the country, not one of the sources. They completely reject democratic principles, as perceived by the West. At the same time, the "Brothers" advocated equal rights for all citizens, while the Salafists denied this point. The basic thesis of the "Muslim Brotherhood" is the construction of a secular state, based on Sharia. The Salafists deny any secular system in the country.

Some researchers believed that in the political Salafists were willing to work with the Muslim Brotherhood to achieve common goals, such as the transition to democracy and the containment of radical and militant tendencies. In the end, they sought to use the pragmatism of the "Brothers" to deprive this leading Islamist movement of the support of religious voters.

Partly they succeeded in this during the parliamentary elections in early 2012. Salafi al-Nour won in western Egypt, resided by more conservative Muslims, bypassing even the FJP ("Muslim Brotherhood") (Islamnews.ru, 2012). In addition, the Salafists sought to take advantage 
of their role as mediators between the Brothers-led government and active in the Sinai area jihadists. The aim was to strengthen their own negotiating positions and to weaken the positions of the Muslim Brotherhood.

Immediately after coming to power, the Muslim Brotherhood appeared under Salafists' pressure. The "Brothers" realized that the Salafists were ready to support them only in the case of a strict policy concerning Sharia. After all, the reason was the presence of various political opponents that Egyptian president Mohammed Morsi (the leader of the Muslim Brotherhood) did not pursue a clear policy of Islamization. The "Brothers" began to balance between the impossibility of implementing the slogan "Islam Hija al-Khal" ("Islam is the solution") and the need of dialogue with the radicals, proving the impeccability of its own Islamic reputation.

An important point is that in the 2012 presidential election, the Salafists initially refused to support the candidate from the "Brothers", and even nominated their own contender. Later after his disqualification, the Salafists eventually called their supporters to vote for Morsi. But taking into account that his opponent in the second round was Ahmad Shafiq, a member of Mubarak's old team that hated radical Islam in previous years, Salafist support of Muhammad Morsi was purely pragmatic.

At the same time, the attitude of "traditional" Islamists towards the Salafists could be called more approachable. After rapidly entering the political arena in Egypt, the Islamists sought for some reliable and ideologically close allies. According to the results of the 2012 parliamentary elections, the Salafi parties turned out to be the largest group in the parliament after the "Brothers". Thus, Muhammad Morsi could not disregard the popularity of ultra-conservative forces.

In any case, in early 2013, when Egypt was shaken by a wave of protests against harsh Islamization policies, it became clear that President Morsi and the Muslim Brotherhood would have to deal with another opposition force that had recently supported them. The dissatisfaction of the representatives of the ultra-conservative parties caused by the fact that they were completely unrepresented in the government despite having won about a quarter of seats in both houses of parliament. 


\section{INFLUENCE OF SAUDI ARABIA ON THE POLITICS OF THE SALAFI PARTIES IN EGYPT}

Following the political process in Egypt, the leadership of the leading Salafi party al-Nour probably came to the conclusion that the Muslim Brotherhood lost much of its popular support, and at this stage of the political struggle, a friendship between parts of a single Islamist movement could damage the political image of pure Islamists.

Ideological flexibility, competent organizational work and, of course, significant funding from Saudi Arabia, interested in supporting Salafism, have allowed al-Nour to become the most influential Islamist party after the Muslim Brotherhood. However, in early 2013, when the "Brothers" began to lose the support of the population, there was a split within the Salafists.

The party's founder, Emad Abdel Ghaffour, and a group of his supporters left al-Nour and founded a separate al-Watan party (Brown, 2013). After the split, these parties chose different political orientations and allies. Al-Watan supported the Muslim Brotherhood to the end, suffering a political defeat with them as a result of the regime change.

The new leaders of An-Nur decided to go in another way. In the summer 2013, when Muhammad Morsi was removed from his post by the Egyptian military, they did not support him and remained silent, waiting for the confrontation between the military and the Muslim Brotherhood to end. A few weeks later, when it became clear that Morsi would not return to power anymore, the Salafists exposed the policies of the expresident and the FJP. The communiqué read that Morsi "did not even try to interact with the military" and that the Freedom and Justice Party began to become the second National Democratic Party (Tsaregorodtseva, 2014) (the ruling party in Mubarak regime).

Hisham Jafar, a columnist of Egyptian political and religious movements, claimed that an-Nur decision to support a military coup led by Field Marshal al-Sisi was rather strange. According to him, the Salafists have gone too far in their support of the military regime in Egypt. From his point of view, al-Nur was too concerned about political competition with the Muslim Brotherhood and attempts to present itself as an alterna- 
tive to the Brothers. Al-Nour suffers from a deep-rooted Salafi intellectual tradition that allows for tolerance of authoritarian rulers to avoid anger on their part (Bayoumi, 2014).

But if these events are addressed from the regional geopolitical prospect, the division of the Salafist movement in Egypt and their support of its part of Egyptian army doesn't look so outlandish. According to A. Bystrov, Arabic scholar from Russia, in 2012 both parties were funded by Saudis and Qataris. Moreover, if Riyadh supported the Salafists, Doha supported the "Brothers" (Byistrov, 2012). Obviously, the plans of the Arab monarchies engaged create a state under their control in a strategically important region for them.

However, since the 90s of the last century the Gulf monarchies have lost their integrity. Qatar has increasingly moved away from subordination to Saudi Arabia. Doha's foreign policy began to rely more and more on the support of the Muslim Brotherhood and their coming to power in Egypt strengthened the regional position of the emirate.

This situation obviously seemed not to be beneficial for the Saudis, who have historically been a leader in the Arabian Peninsula. Riyadh sought to undermine the position of the Muslim Brotherhood through the support of the Egyptian Salafists. In 2013, when Muhammad Morsi's legitimacy reached a tipping point, Saudi Arabia began demanding from Salafi parties to support the Egyptian military, led by Field Marshal al-Sisi. That is why the split took place, as some activists, committed to their own ideology, did not agree to these demands. As a result, they left the ranks of the alNour party. Their representatives, such as Emad Abdel Ghaffour, spoke purely from an ideological standpoint. They believed that previous expressions of will clearly indicated that the population supported the policy of Islamization, so they could not betray their voters, who voted for the return of the state to the plane of Sharia.

Another camp, led by the new leader of the al-Nour party, Eunice Mahun (elected in January 2013 after the removal of Abdel Ghaffour), quickly adapted to European rules of political struggle. For them, the decisive factor was the struggle for power, not their own ideological positions. This, in fact, was the reason for the division of the Salafi movement. 
This view is corroborated by numerous statements, voiced by the "Salafi Call" leaders. In particular, Khalid Adam ad-Din stated, "Rationalism and realism are part of Salafi teachings. We believe that in times of crisis we can choose the bad to avoid the worst." Muhammad Salah, a member of the Salafi party's media committee, noted that Sisi does not belong to any of the political parties and does not represent the interests of any one ideology, which makes his candidacy the most acceptable for many Egyptians. According to Salah, as-Sisi also "understands better than others the foreign threats facing Egypt." Eunice Mahun told local media that his party had many reasons to support al-Sisi, including "his strategic vision and administrative experience in the armed forces" (Bayoumi, 2014).

These events vividly describe the process of Wahhabization of the Egyptian Salafists. In order to continue to receive financial assistance from Riyadh, most members of the movement departed from the fundamental principle of the ideology of "pure" Salafism and submitted to the Saudi dynasty. These actions led to the fact that both parts of the Egyptian Salafists have almost completely left the political space of the state.

\section{CONCLUSIONS}

Our findings would seem to show that as a result of the Egyptian events of 2011-2013, Salafism failed to enter the space of Western-style political struggle. Numerous researchers assure that the reasons for the party's failures were related to the desire of Salafist leaders to use Al-Nour solely as a tool for lobbying their ideas. The party's goal was not to come to power, but to spread Salafist views and establish control over as many mosques as possible (Lacroix, 2016).

In addition, the growing popularity of jihadist movements also contributed to the political defeat of the Salafists in Egypt. The Salafi parties in the legal political field were conservative but generally peaceful; they intended to achieve their goals by democratic means. Some observers believed that the expulsion of the Muslim Brotherhood from Egyptian politics was useful for Salafists, as the "Brothers" were their main rivals in the Islamist part of the political spectrum. However, the removal of Morsi 
by military means resulted into a loss of confidence among the broad Muslim population in the peaceful political process. Some Al-Nour supporters, seeing that the party supported the military coup, concluded that it had abandoned the Islamic project.

The policies of Saudi Arabia and Qatar played an important role here. The desire of both Gulf monarchies to strengthen their positions in the region by influencing other states played a nasty joke on them. As a result of the support of different Islamist forces in Egypt and their incitement to confrontation, both the Muslim Brotherhood and the Salafists have failed.

There is evidence to suggest that heterogeneity of the Salafi movement in Egypt was perhaps the main reason for their failure to enter the political space. The absence of a recognized leader and the large number of approaches to the role and activities of al-Nour in the political arena were complicated by the choice of priorities of the religious component over the political and vice versa. The popularity of the Salafi parties was hampered by the lack of clear boundaries between the religious and political activities of the Salafists. Al-Nour felt strong pressure from members of the religious movement, which led to the resignation of some of its members.

At the beginning of Arab Spring hopes were cherished that if radical forces join the political mainstream, their extremism will be eventually abandoned. This forecast worked well for the political sphere only. The politicization, gradual liberalization, and deideologisation of the main Salafist movements, their rationalism in the political sphere, caused a loss of support among the religious part of society, which had previously provided them with serious political weight. In Egypt, the Salafists failed to reach a common denominator in adopting a common methodology for their own political activities. As a result of a lack of political experience, Al-Nour failed to increase its success in 2012, and after the removal of Mohamed Morsi from the office, Salafism receded to the periphery of Egyptian politics, where it remains to date. 


\section{BIBLIOGRAPHY:}

Bayoumi, A. (2014). Egypt's Salafi party faces growing isolation. Aljazeera. Retrieved from: https://www.aljazeera.com/news/middleeast/2014/05/egypt-salafi-party-facesgrowing-isolation-2014514111139164795.html.

Bokhari, K. (2012). Salafism and Arab Democratization. Stratfor. Retrieved from: http:// www.stratfor.com/weekly/salafism-and-arab-democratization?utm_source=freelistf\&utm_medium=email\&utm_campaign $=20121002 \& u t m \_t e r m=g w e e k l y \& u t m \_c o n$ tent $=$ readmore\&elq=d3a9bcf81be9497e85626cd52f04758b\#axzz3D5ocHutE.

Brown, J. (2013). The Rise and Fall of the Salafi al-Nour Party in Egypt. Jadaliyya. Retrieved from: https://www.jadaliyya.com/Details/29813.

Byistrov, A.A. (2012). Egipet: situatsiya posle parlamentskih vyiborov [Egypt: the situation after the parliamentary elections]. Institut Blizhnego Vostoka. Retrieved from: http:// www.iimes.ru/rus/stat/2012/01-03-12a.htm (accessed 16 Jan. 2020) [in Russian]

Dagher, S. (2012). Arab Media Clash Over Syria. The Wall Street Journal. Retrieved from: https://www.wsj.com/articles/SB10001424052970203961204577269081450598296.

Egerton, F. (2011). Jihad in the West: The Rise of Militant Salafism. Cambridge: Cambridge University Press.

Esposito, J. (1992) The Islamic Threat: Myth or Reality? New York: Oxford University Press. Islamnews.ru, (2012). Na zapade Egipta salafityi oboshli «Bratev-musulman» [In western Egypt, the Salafis have bypassed the Muslim Brotherhood]. Islam News. Retrieved from: https://islamnews.ru/news-Na-zapade-Egipta-salafity-oboshli-Bratev-musulman (accessed 16 Jan. 2020). [in Russian]

Lacroix, S. (2016). Egypt's Pragmatic Salafis: The Politics of Hizb al-Nour. Carnegie. Retrieved from: http://carnegieendowment.org/files/Brief-Lacroix_al-Nour_Party. pdf.

Lacroix, S. (2012). Sheikhs and politicians: inside the new Egyptian salafism. Retrieved from: https://www.brookings.edu/wp-content/uploads/2016/06/Stephane-LacroixPolicy-Briefing-English.pdf.

Lewis, B. (1988). The Political Language of Islam. Chicago: University of Chicago Press. Mitchell, R. (1993). The Society of Muslim Brotherhs. Oxford: Oxford University Press. Mukhtasar Sahih Muslim. Hadith, No. 1066.

Mohamed, A. (2015). Roots of Religious Extremism, The: Understanding the Salafi Doctrine of Al-Wala' Wal Bara'. London Imperial College Press.

Razhbadinov, M.Z. (2013). Anatomiya egipetskoy revolyutsii - 2011. Egipet nakanune i posle politicheskogo krizisa v yanvare-fevrale 2011 goda [Anatomy of the Egyptian Revolution - 2011. Egypt before and after the political crisis in January - February 2011]. Moskva: IV RAN. [in Russian] 
Said, E. (1997). Covering Islam. New York: Vintage.

Tsaregorodtseva, I.A. (2014). «Bratya-musulmane» i salafityi Egipta nakanune i posle «revolyutsii 25 yanvarya» ["Muslim Brotherhood" and Salafis of Egypt on the eve and after the "January 25 revolution"]. Institut Blizhnego Vostoka. Retrieved from: http:// www.iimes.ru/?p=19677 (accessed 16 Jan. 2020). [in Russian]

Tsaregorodtseva, I.A., Ibragimov, I.E. (2018). Sovremennyiy salafizm: genezis, istoriografiya i tipologiya dvizheniya (na primere Egipta i Tunisa) [Modern Salafism: Genesis, Historiography and Typology of the Movement (on the Example of Egypt and Tunisia)]. Islamovedenie, 9 (3), pp. 5-18. [in Russian]

Wight, C. (2009). Theorising Terrorism: The State, Structure and History. International Relations, 23(1), pp. 99-106.

Wiktorowicz, Q. (2006). Anatomy of the Salafi Movement. Studies in Conflict \& Terrorism, 29(3), pp. 207-239. 